\title{
A Grand Tradition of Struggle
}

Cornel West

Cornel West, professor of religion and African American studies at Harvard University, delivered an inspiring speech at the 1994 NCTE Annual Convention. Though this presentation was delivered six years ago, West's comments are particularly significant as we think about English language arts instruction into the next century. In his latest book, The Cornel West Reader, he elaborates on the points raised in the speech. When I spoke with him about this book and the speech, he reemphasized the respect and admiration for the English teaching profession present in both. He also shared a belief in the significant role English teachers can play in reinvigorating the democratic tradition in the United States and abroad.

Dale Allender

Associate Executive Director, NCTE

$\prod$ am always deeply humbled when I am in the presence of English teachers, the major reason being that I have had teachers of English who have meant so much to me. I think of Mrs. Kay and Mrs. Angel and Mrs. Sol, who walked us though the poetry of Eliot and the novels of Charles Dickens and George Elliot on through James Ball. They didn't get to Toni Morrison, unfortunately. Opening worlds and broadening horizons for one who grew up in working class, segregated Sacramento, California, made a difference, a big differencethe same way each and every one of you is making a difference.

I am a small part of a great and grand tradition, a tradition of struggle, a struggle for decency and dignity, a struggle for freedom and democracy. When I think of Sojourner Truth, Harriet Tubman, Ida B. Wells Barnett, A. Randolph, Marcus Garvey, Ella Baker, Fanny Lou Hamer, and Zora Neale Hurston, I am humbled and feel dwarfed by their standards of vision and courage, of service and sacrifice. I think of Lydia Maria Child, a white sister in the early part of the nineteenth century, an educator and activist, who wrote that classic appeal in favor of the class of Americans called Africans. How she would care for the family of brother John Brown after he was executed in December of 1859. And Elijah Lovejoy, another white brother, educator and journalist, murdered in 1837 at Alton, Illinois, with his press thrown into the Mississippi river owing to his abolitionist activity. Or
Miles Horton, known to some as cracker and white trash, but what a towering prophetic figure in the history of American education-founder, along with James Dobronski, of the Highlander Center in Tennessee that would help train, as he was trained, Rosa Parks, Robert Moses, Stokley Carmichael, Diane Nash, and a whole host of freedom fighters. This is a tradition that I am a proud product of and participant in. It is a joy to be a small part of such a cloud of witnesses.

And I believe old Thomas Stearns Eliot, though of a very different ideological slant than myself, towering poet that he was, challenging critic that he was, when he wrote in his famous essay of 1919, "Tradition and Individual Talent," that tradition is not something you inherit. If you want it, you must obtain it with great labor. I would add toil and 
engagement and service. The fundamental question I would like to raise is, "What are the ways in which we can keep alive this tradition of struggle for decency, dignity, freedom, and democracy?"

Now for me, in all honesty, I begin with trying to come to terms with what I call loosely the new world African encounter with the absurd. What is that absurd? It is the sheer irrational, capricious, and arbitrary defining of humanity based on skin pigmentation. One does not have to read John Paul Sartre or Albert Camus to know what the absurd actually is when one undergoes assault, attack on black beauty. The practice of white supremacy and its legacy begins with the degradation of the black body in order to control, economically exploit, politically oppress, and culturally degrade it. We should never forget that race itself, a legal and cultural construct with no scientific content or validity, a construct that has produced such devastating consequences, began with an aesthetic devaluation of black bodies.

\section{It is a joy to be a small part of such}

\section{a cloud of witnesses.}

Francois Burney in 1684 first put this notion forward. And Johan Frederick Bloomingbach in his text published the same year as The Wealth of $\mathrm{Na}$ tions and the Declaration of Independence, a text called Natural Varieties of Humankind, lists in hierarchical ranking the physical characteristics of human bodies and then tries to make links between those characteristics and beauty, intelligence, moral character, capacity, and capability. This way in which race was constructed is a thoroughly modern affair; no one had thought about dividing humankind by appealing to observable and physical characteristics until the age of Europe took off, beginning in 1492. In the 1680s and the 1730s it began to take on force.

And so many began to believe it, to take it seriously, to give it a structure of meaning and value, to institutionalize it in the nation's state and economy, in our customs and mores, ways of looking at ourselves and our bodies, and defining our desires and our pleasures. It cut very deep. Of course, it has come at us now with Mr. Murray and the late Mr. Hernstein in the Bell Curve. One can sit in the black barbershop and revel in that wonderful sense of comedy that one finds among oppressed peoples around the world and hear, "In the eighteenth century they said we had no intelligence, in the nineteenth century they said a few had some intelligence, in the twentieth century they say most of us have less intelligence, we're making progress!" Given white supremacist criteria, we're making progress. It was John Day Chapman who said that white supremacy is like a serpent wrapped around the legs of the table upon which the Declaration of Independence was signed by the founding fathers. It haunted this precious yet precarious experiment in democracy then, and 218 years later it continues to haunt us.

It is no accident that when Americans as a people decide to confront the legacy of white supremacy, it raises the deepest question of who we are individually because it forces us to explore that wilderness inside of each and every one of us called ourselves. It also forces us to come to terms with the ambiguous legacies of our past. W.E.B. DuBois is probably the best starting point for a discussion about race in America. He begins with a poem by Arthur Simmons, that symbolist critic and mediocre poet, but fascinating figure. He wrote a poem called "The Crying of Water," published September 18, 1900. He went mad two and a half months later. In those thirteen lines are eight references to cries, guttural cries, echoing the cries of Africans who jumped off or were tossed off slave ships, represented so graphically by the great Turner and his slave ship painting. DuBois then moves to musical bars, Negro spirituals: Nobody knows the trouble I've seen / Nobody knows but Jesus / Nobody knows the trouble I've seen / glory halleluiah. DuBois says in the first paragraph, between me and the other world there is an unasked question; most people flutter around it, avoid it. And the question is this: How does it feel to be a problem? How does it feel to be a problem in a civilization that has put such high premium on problem solving? DuBois is saying, How does it feel to have not only one's humanity problematized, but how does it feel to be cast as part of a problem people, rather than people with problems? We all have problems. Each and every one of us face despair, disappointment, disease, anxiety, fear, worry. But that's very different from being cast as part of a problem people, as part of some undifferentiated blob, some monolithic and homogeneous conglomerate, which makes all black folk interchangeable and substitutable. Only 
need to ask one what the rest of them think. They all have the same values and same sensibilities and sentiments. I experienced this oftentimes in college. When I was the only black student sitting there, issues of race would emerge, and they would all look at me and say, "Yes, Cornel, what does Black America think about that?" "I don't know, I haven't engaged in a wholesale imperial investigation. I can tell you what this one thinks." Even on a national level, when brother Jesse Jackson was running for president, one of the national magazines raised a question, "What does Jesse want? If we could just find out what Jesse wants, we could find out what they want." It didn't occur to them that maybe what Jesse wants is what Jesse wants.

\section{The practice of white supremacy}

\section{and its legacy begins with the}

$$
\text { degradation of the black body in }
$$

order to control, economically

exploit, politically oppress, and

$$
\text { culturally degrade it. }
$$

But what we are talking about here is something very serious, namely the grand metaphor invoked by the late, great Ralph Ellison in his novel of 1952, Invisible Man. Forty-two years after the publication of that novel, it still has such pertinence for people whose epidermus is most visible, who find their humanity, individuality, diversity invisible - the raw stuff for stereotypes, viewed as abstractions and objects, rather than individuals and persons. And when they become visible, it usually takes two forms, either as exotic object or transgressive object. Exotic - closer to nature, further removed from rationality and intelligence. Transgressive-source of white fears and anxieties-reinforced, of course, by the veil, the thick walls of demarcation between black world, white world, black world, red world, black world, yellow world, black world, brown world that makes it not simply difficult to build bridges, but makes it difficult for communication to take place owing to the various myths and distortions, stereotypes that evolve around each group.

To talk about the legacy of white supremacy is in many ways to echo the great DuBois when he said the problem in the twentieth century will be the color line. DuBois assumed that the twentieth century would be a century in which the struggle for democracy would expand, and he saw white supremacy as a major impediment for the expansion of democracy, not simply in the US, but around the world with European colonial imperial powers. How do we come to terms with race and white supremacy on a global scale? How is it distinctive in the US given that we are the grand experiment so far in democracy and yet that democracy was predicated on black subordination and subjugation? Murdock called it a dilemma; I call it sheer hypocrisy. How do we confront it critically, candidly in such a way that we highlight the best of each and every one of us but remain frank and candid in terms of the psychic scars, existential bruises, and ontological wounds that have been left by this legacy of race?

Well, for me, any talk about white supremacy is linked to talk about male supremacy, vast economic inequality, homophobia, and losing sight of the humanity of a physically challenged person. Why? Because to talk about white supremacy is, in fact, ultimately to talk about the ways in which one keeps alive a democratic tradition. White supremacy is simply one particular way of looking at the world that loses sight of the humanity of a slice of the human family. There was once a brother who played the organ for my church, Shiloh Baptist Church in Sacramento, California. We knew him as Sylvester, but he's known to the world for the genius that he is; his name is Sly Stone. He wrote a powerful song called "Everyday People." Speech of Arrested Development picked it up and called it "People Every Day," and the younger generation updated it, postmodernized it a bit, but the point is still the same: the lives of everyday people are shot through with a sense of the majestic, the tragic, and the problematic. Each and every one of us as everyday people is unique and distinctive, singular and irreducible, and therefore of equal value. That sounds simple, but in fact it is profoundly subversive.

For most of human history, everyday people have been viewed as raw material to be used and abused in order to sustain the refined lifestyles of 
the few. The history of humankind is in part the history of the coercing and forcing of everyday people to defer to some set of unaccountable elites, be they kings, queens, princes, prelates, potentates, magistrates, lords, earls, squires, shoguns, or czars. Of course, the assumption is that everyday people's lives are one-dimensional. This was true even among the Greeks, in their grand experiment in democracy in Athens, with its preconditions, imperial domination, patriarchal households, and resident aliens, like Aristotle, who could not vote.

\section{The history of humankind}

$$
\text { is in part the history of }
$$

\section{the coercing and forcing}

$$
\text { of everyday people to defer }
$$

\section{to some set of unaccountable}

$$
\text { elites, be they kings, queens, }
$$

princes, prelates, potentates,

$$
\text { magistrates, lords, earls, }
$$

$$
\text { squires, shoguns, or czars. }
$$

There are Promethean energies among everyday folk that, if unleashed, produce possibilities heretofore ignored and downplayed and overlooked. You can't make premature judgments as to what those energies actually are; just try to cultivate and unleash them and see what happens. That is one of the reasons why jazz is a great democratic art form, and I would argue one of the greatest cultural contributions of American civilization, because it is predicated on the notion that these everyday people can aspire to the level of genius. Miraculous activity is shot through the everyday, such that a John Coltrane from Hamlin, North Carolina, can ascend to a level of genius by what? By hanging out with everyday folk who have created forms of discipline and affirmation that surprise themselves and the world and allow every individual his or her part in the performance. There is no conductor who subordinates the rest, but, like Duke Ellington, the conductor is alongside the others, allowing the others' voices to be heard so that the dialectic between individuality and collectivity can mesh in such a way that ascends to a level of performance that heretofore was new, different. What a sonata! Democracy in action, created by everyday people.

No one of us or one group has the truth, capital "T," but rather has argument, visions, and perspectives that can grow and be strengthened as they interact, listen to, are informed by those of others in a public sphere, a public life, a public conversation, mediated with mutual respect and civility. Those are just the preconditions for democracy. And when we look at the history of democracies, we see that they usually unravel owing to increasing poverty that produces escalating levels of despair and increasing paranoia that produces escalating levels of distrust. And to talk about race in America is to talk about poverty and paranoia, despair and distrust. There are too many black poor people, too many brown, too many yellow, too many poor people in America. Poverty crushes the spirit of so many. Paranoia, distrust, and suspicion exist between the Black-White, Black-Red, Black-Yellow, Black-Brown worlds that I alluded to earlier. When I look at the state of American democracy, I conclude we are living in one of the most frightening and terrifying moments in the history of this republic.

One percent of the American population owns 48 percent of the total net financial wealth; 2.5 million citizens have control of 8 billion of the 20 billion dollar pool. That sounds oligarchic, plutocratic, to some significant degree, pigmentocratic. But for the most part, it is unconstitutional for the federal government to tax wealth. It can only tax income, which means redistribution of the tax burden, downward. And yet 20 percent of all of America's children live and die in poverty, and 42 percent of young brown brothers and sisters live and die in poverty, and nearly 51 percent of young black children live and die in poverty in the richest nation in the history of the world.

This relative economic decline, which is inseparable from, though by no means identical to, the undeniable cultural decay, serves as a backdrop for any serious talk about education in America. 
One cannot talk about the school without talking about family and community, quality of life and motivation, and the undeniable cultural decay of our time. In some ways this relative erosion of the systems of nurturing and caring, especially for young people, is a distinctive feature of the decline of every civilization we have known going back to the Sumerians and Mesopotamians and the Egyptians of Northern Africa. And it is not just a question of family. The family is in trouble, in chocolate cities and vanilla suburbs, no doubt. But we also know that when the nuclear family was in place, it took more than two people to raise children. You needed teachers and aunts and uncles and grandmothers and grandfathers and deacons and deaconesses and pastors and rabbis and ministers and little league coaches and dance teachers and still a little luck and grace to raise children.

\section{There is no way to make it}

\section{from womb to tomb without} some stories and rituals

\section{and communities.}

What then are we to do? We need to promote a highly un-American quality: a sense of history. Some say history is bunk. One can fly from tradition and hold the past at arm's length. But history comes back to haunt us. Huck may want to stay on that boat. He does not want to land for long, too much history. But there's Brother Jim standing. Samuel Clemens/Mark Twain is too deep, too nuanced, too sophisticated to fall prey to a thin, melodramatic conception of history. He knew history was tragic_-blood, sweat, and tears shaped by conscious and unconscious elements. There is no escape from history. We ought not to be paralyzed by it, but there is no escape from it, and refusing to come to terms with our own ambiguous legacies of the past is to fall prey to the worst of the economic decline that highlights the worst of us. One of the fundamental rules and functions of literature and language is to allow us to situate ourselves in stories and narratives about the past that are bigger than we are individually, sto- ries and narratives that were in place before we arrived and will be in place in new and revised forms after we are gone. There is no connection to this larger story and a larger narrative, so community and ritual are rendered ruthless, naked, culturally naked, like oranges without a peel. There is no way to make it from womb to tomb without some stories and rituals and communities.

A sense of history is so very important to allow us to get beyond it. Without confronting it, there is very little chance. A sense of history would serve the crucial pillar for the kind of public conversation that we need to have about race, class, gender, and sexual orientation-not name calling and finger pointing, but an exchange of arguments and perspectives-because much is at stake, whether that stake is the relative success or relative failure of an experiment in democracy called America. It could easily slide down a slippery slope to disorder, anarchy, and chaos. That again brings out the worst in each and every one of us.

That sense of history ought to be linked to an expansion of empathy. There is a shrinkage of the empathetic imagination in our day. Literature and language are the primary means by which we learn what it is like to get inside the skin of others who are different from ourselves. What is it like to identify with the frustrations, insecurities, and anxieties of other persons, especially those on the other side of the veil? John Griffith's book, Black Like Me, published in 1951, is a crucial text for this country. A white brother wants to find out what it's like to be black and wants to do more than simply turn on the television and imagine it as a vicarious experience. He actually changes his epidermus, injects melanin. He planned to be black for three months; he lasted twenty-nine days. God bless him, it was tough. But he lived to tell a powerful story, and that story reflected a time in which there was a will to want to identify with the plight of other people. The imagination was available because there were others who were putting a premium on that will. We live in a time in which people just lose interest. That is primarily what the Hernstien book is about. It is not about IQ. It is primarily about the perception that says, "Look, the problems of these poor people of all colors-but disproportionately black and brownare intractable. You can't do anything; don't feel bad about it; you're hitting your head against the wall; you're having very little effect; there's nothing you can do; soothe your agonized conscience. It's 
part of the nature of things." How frightening. Even though it speaks to a deeper truth, at times it does seem intractable. And yet somehow we have got to muster the will to still want to get inside the skin and walk a mile in the shoes of our young people of all colors and never give up on them as potential citizens who can contribute to the life of this nation.

Third, something called courage in the form of self-criticism. How do we get beyond simply having the courage of our convictions and actually have the courage to attack our convictions? The only way we can grow and mature is by taking seriously what Socrates said - the unexamined life is not worth living. But then we can add the insight of Malcolm X that the examined life is painful. It hurts. It leaves us vulnerable. And, of course, good teaching is all about unsettling perspectives and unstiffening prejudices and allowing persons to be emancipated and liberated from whatever parochial cocoon they find themselves in at the moment. Each and every one of us is always linked to some parochial cocoon; we are never free. It is a perennial process that takes courage.

Last but not least, we need more than anything else a sense of audacious hope. This has very little to do with optimism. I am not optimistic about American democracy or American education; I don't believe the prevailing evidence allows me to infer that things are going to get better, even given those who are struggling gallantly. But I am a pris- oner of hope. I can look beyond the evidence and create new evidence. I can make leaps of faith to try to energize and galvanize each and every one. We've got to cut radically against the grain and go flagrantly against the odds if we are going to be true to the democratic tradition.

So I say to you that I hope and pray that you will keep your heads to the sky, doing the crucial work that you are doing, to keep your hands on the plow, even when it takes the form of unadvertised service, even when you feel you are in a deep freeze, and you want things to melt a bit, and they don't. I hope that you will conclude with me that, even in these difficult times, the world is incomplete and history is unfinished and the future is open ended, and what we think and do can make a difference, individually and collectively. If we believe that enough, and keep our eyes not so much on each other but on the prize, something bigger and better than us that can appeal to the best in us, appeal to the bettering of our nature, we may in fact have a chance of regenerating and rejuvenating American democracy. T. S. Eliot said, "Ours is in the trying, the rest is not our business." I think, again, he is right. And I can simply say to those who are willing to meet the challenge and keep alive the democratic tradition, that I'll be there with you, because I'm going down fighting.

CORNEL WEST is a distinguished professor of religion and African American Studies at Harvard University.

EJ 20 Years AGO

\title{
Political Connections
}

\begin{abstract}
"What we do in the classroom is intimately connected to what happens outside of it. Politics defines the job of teaching when we teach irony, unity and main idea, as long as those are connected to something-literature, written policies of school boards, or student papers. Knowledge and skills can't be taught in a vacuum. When students make the connections we hope for, both teachers and students have been engaged in politics, and we take pleasure in that transaction even though we may not like to think of it as political."
\end{abstract}

H. Thomas McCracken. “The English Journal and NCTE Should Stay out of Politics: Rebait.” EJ 69.6 (1980): 8-11 